\author{
Sylwia NOWAK \\ Dr, Instytut Geografii i Przestrzennego Zagospodarowania im. Stanisława Leszczyckiego, Polska Akademia Nauk, Warszawa \\ e-mail: sylnow@gmx.de
}

\title{
CZYNNIKI KSZTAŁTUJĄCE WARUNKI ŻYCIA W PIOTRKOWIE TRYBUNALSKIM PO TRANSFORMACJI USTROJOWEJ
}

\begin{abstract}
Abstrakt: W artykule przedstawiono diagnozę warunków życia w Piotrkowie oraz czynników na nie oddziałujących w kontekście konsekwencji transformacji ustrojowej Polski w oparciu o dostępne materiały źródłowe, jak i własne badania. Decydujące oddziaływanie na poziom zadowolenia mieszkańców z własnego środowiska zamieszkania ma w świetle wyników pracy estetyka zabudowy. Szczególnie ważne jest dla nich ponadto rozmieszczenie w najbliższej okolicy obiektów usług społecznych: podstawowej opieki zdrowotnej oraz bibliotek.

Słowa kluczowe: warunki życia, jakość życia, poziom życia, usługi społeczne.
\end{abstract}

\section{FACTORS SHAPING LIVING CONDITIONS IN PIOTRKÓW TRYBUNALSKI AFTER THE SYSTEM TRANSFORMATION}

Abstract: The paper describes a very complex research problem of urban living conditions in Piotrków Trybunalski and factors affecting them in the context of consequences of the system transformation in Poland. The analysis employs objective indices describing living, housing, working and leisure/recreation conditions in Piotrków Trybunalski. The knowledge about the level of the local community need satisfaction has been gained as a result of a field measurement on a representative (random) sample of Piotrków Trybunalski inhabitants. The key element affecting the level of satisfaction among inhabitants with their own residential environment is in the light of the work results the building aesthetics and the availability of social services (especially primary healthcare facilities and public libraries).

Keywords: living conditions, standard of living, quality of life, social services.

\section{WPROWADZENIE}

Piotrków Trybunalski należy do miast, w których zaznaczyły się negatywne konsekwencje przebiegu procesu transformacji, upadku wielu przedsiębiorstw przemysłowych oraz utraty funkcji ośrodka wojewódzkiego. W warunkach gospodarki rynkowej władze miasta zmuszone zostały do poszukiwania nowych szans, które mogłyby stanowić podstawę jego trwałego rozwoju, gdyż dotychczasowe jego atrybuty, takie jak np. centralne położenie w kraju, rezerwy taniej siły roboczej i tereny dogodne dla zabudowy przemysłowej i mieszkaniowej w obecnych warunkach są niewystarczające. Celem autorki artykułu było wskazanie czynników oddziałujących na kształtowanie się warunków życia ludności Piotrkowa Trybunalskiego po transformacji ustrojowej $\mathrm{z}$ uwzględnieniem ich roli w zróżnicowaniu przestrzeni miejskiej.

\section{DEFINICJE I PROBLEM BADAWCZY}

Według A. Hodoly'ego (1975), warunki życia określane są przez całokształt czynników determinujących zaspokajanie potrzeb ludzkich. Ich klasyfikacja w literaturze przedmiotu jest dość spójna, przy czym wyróżnia się czynniki endo- i egzogeniczne. S. Liszewski (2004) proponuje zaś, by w badaniach nad warunkami życia przyjąć, że są one zmienne w czasie i przestrzeni. Zmienność czasowa zależy w dużym stopniu od czynników zewnętrznych (egzogenicznych), natomiast strukturę przestrzenną warunków życia w mieście regulują głównie czynniki wewnętrzne (ednogeniczne). J.J. Parysek (2005) uwzględnił wśród czynników endogenicznych kształtujących współcześnie miasta Polski: 1) zmiany ustrojowe, 2) działania samorządu terytorialnego, 3) zmiany demograficzne, 4) rewitalizację i 5) marketing miejski, natomiast wśród egzogenicznych: 1) globalizację, 2) metropolizację, 3) przemiany postindustrialne oraz 4) integrację europejską. 
Warunki życia (wg Liszewskiego 2004) oznaczają ogólny stan zaspokojenia wszelkich potrzeb życia i działalności człowieka. Z kolei J. Regulski (1982) uznał, że skoro człowiek zaspokaja swoje potrzeby poprzez kontakty z otoczeniem, to warunki życia można zdefiniować jako „relacje zachodzące między poszczególnymi ludźmi a ich otoczeniem". Niezależnie od przyjętej definicji, człowiek realizując swoje potrzeby szuka najbardziej sprzyjających warunków, a wynik ich porównania jest siłą napędową przemieszczania się ludności. Owe porównania możliwe są dzięki miernikom opisującym poziom i jakość życia.

Poziom życia jest oceną stopnia zaspokojenia potrzeb człowieka. J. Drewnowski (1974) zwraca uwagę, iż są one zaspokajane w wyniku korzystania przez człowieka z dóbr, usług i warunków życia w danej jednostce czasu. M. Pohorille (1977) skłania się ku zawężeniu tego pojęcia do zaspokojenia potrzeb ekonomicznych za pomocą dóbr materialnych i usług. Szersze rozumienie potrzeb wprowadza S. Liszewski (2004), który proponuje, aby poziom życia określać jako stopień zaspokajania nie tylko potrzeb materialnych, lecz iduchowych człowieka. W niniejszej pracy przyjęto definicję, według której poziom życia stanowi standard warunków życia panujących w określonym miejscu i czasie. Opisowi stopnia zaspokojenia potrzeb służą parametry ilościowe, które można między sobą porównywać.

Więcej problemów wiąże się z jakością życia. Jest to parametr, który opiera się na zindywidualizowanym systemie ocen, wobec czego trudno jest go zmierzyć i porównywać. Najszerzej pojęcie jakości życia definiuje T. Słaby (1990), wskazując że na jakość życia składają się wszystkie elementy życia człowieka, które wiążą się z odczuciem spełnienia i satysfakcji. R. Gillingham i W.S. Reece (1980) proponują, żeby jakość życia jednostki opisywać jako poziom satysfakcji, jaki uzyskuje ona w wyniku korzystania z dóbr i usług nabywanych na rynku, spożycia dóbr publicznych, form spędzania wolnego czasu i pozostałych charakterystyk (materialnych i społecznych) środowiska, w którym się znajduje. S. Liszewski (2004) skłania się natomiast ku bardziej syntetycznemu podejściu - by jakość życia rozumieć jako stopień zadowolenia człowieka z warunków życia, czyli ze stanu w jakim żyje. Jakość życia zależy nie tylko od warunków istniejących, lecz także od warunków pożądanych, nie stanowi zatem ona wielkości obiektywnej. Dlatego jej opisywanie wymaga uwzględnienia subiektywnych potrzeb mieszkańców.
W polskiej geografii (podobnie jak w socjologii miast) badania warunków życia mają stosunkowo krótką tradycję (Liszewski 1995, Zborowski 1989, Misiak 1992), co wiąże się m.in. z trudnościami teoretycznometodologicznymi wynikającymi z braku odpowiedniej bazy źródłowej. Taki stan faktyczny czyni niezwykle trudnym zadaniem prowadzenie kompleksowych badań zróżnicowania przestrzennego jakości i poziomu życia w polskich miastach.

W literaturze anglosaskiej (Rogerson 1999) można znaleźć uporządkowaną propozycję bardzo szerokiego rozumienia pomiaru jakości życia sensu largo. Obejmuje ona dwa typy podejść badawczych. W pierwszym autor proponuje korzystanie ze zbiorów danych obiektywnych (np. ze statystyk publicznych), a w drugim (zawierającym elementy ocen subiektywnych) wykorzystuje się zindywidualizowane kwestionariusze badawcze (ang. survey). Z kolei pomiar jakości życia sensu stricto związany jest wyłącznie $\mathrm{z}$ badaniem subiektywnego dobrostanu jednostek i zbiorowości ludzkich. W ramach prowadzonego przez GUS „Badania spójności społecznej" skoncentrowano się zatem na dwóch wymiarach jakości życia - obiektywnym oraz subiektywnym (dobrostanie), kierując się metodologią przyjętą w raporcie J.E. Stiglitza i in. (2009). We wnioskach autorzy tych badań podkreślają, że kompleksowa analiza jakości życia powinna obejmować oba podejścia, a podobieństwa w mechanizmie kształtowania i objaśnienia tych zjawisk wskazują na liczne współzależności między nimi i stanowią wsparcie dla koncepcji łączącej te zjawiska w pewną większą całość tematyczną. Dlatego miary subiektywne powinny być stosowane obok, a nie zamiast wskaźników obiektywnych, by dokonać możliwie pełnego i rzetelnego opisu zjawiska. Z łączonego podejścia korzystają autorzy Diagnozy społecznej 2013(Czapiński, Panek, red. 2014).

\section{METODOLOGIA BADAŃ WARUNKÓW ŻYCIA W PIOTRKOWIE TRYBUNALSKIM}

Diagnozę warunków życia panujących w Piotrkowie Trybunalskim przeprowadzono (ze względu na ograniczoność zbioru danych GUS oraz kontekst definicyjny) w oparciu o badanie stacjonarne (ang. desk research) oraz pomiar (sondaż) terenowy (por. rys. 1). Materiałów poszukiwano w Urzędzie Miasta (Biurze Rady Miasta oraz Pracowni Planowania Przestrzennego), a także w zbiorach GUS w Warszawie i jego piotrkowskim oddziale terenowym. Ponadto przeprowadzono kwerendę w Miejskiej Bibliotece Pub- 
licznej w Piotrkowie Trybunalskim, Bibliotece Uniwersyteckiej w Łodzi, Czytelni Naukowej Biblioteki Publicznej Dzielnicy Bemowo m. st. Warszawy oraz Centralnej Bibliotece Geografii i Ochrony Środowiska IGiPZ PAN.

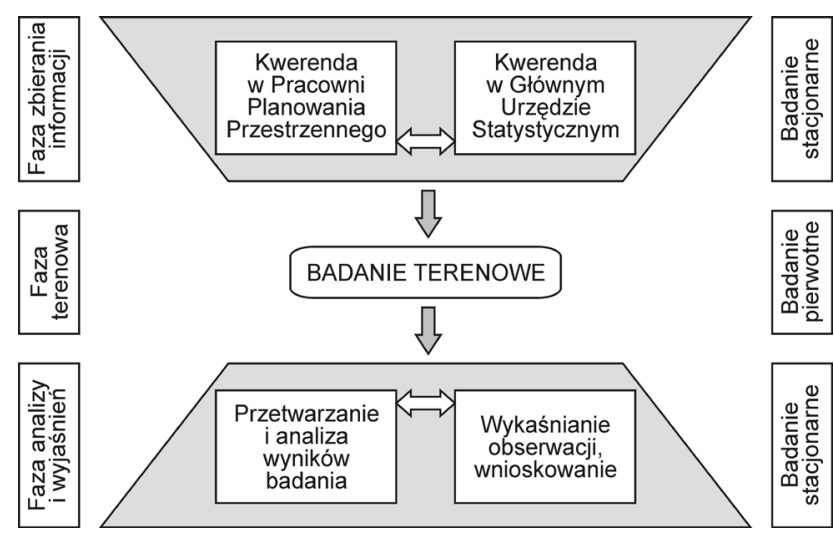

Rys. 1. Przebieg procesu badawczego Źródło: opracowanie własne

Faza terenowa polegała na realizacji w marcu 2012 r. sondażu ankietowego. W badaniu tym zdecydowano się na zalecany przez geografów o orientacji scjentystycznej dobór próby metodą reprezentacyjną (Matykowski 1992), tj. częściowego badania statystycznego opartego na próbie losowej. Przeprowadzono więc losowy dobór próby ze skończonej zbiorowości generalnej (spisu adresów z bazy PESEL dla Piotrkowa Trybunalskiego, z 2010 r.). Badaniem objęto cały obszar administracyjny miasta, a w wyznaczonych uprzednio dzielnicach (warstwie) zastosowano dobór systematyczny. Przy określeniu wielkości próby założono przedział ufności 0,95 i wielkość frakcji 0,5, akceptując to, że przy interpretacji wyników analizy będą obarczone maksymalnym błędem pomiaru równym 5\%. Wielkość próby wyniosła $n=450$ mieszkańców Piotrkowa Trybunalskiego. Interpretacja wyników była możliwa zarówno dla całego miasta, jak i poszczególnych jego dzielnic.

\section{CZYNNIKI ENDOGENICZNE KSZTAŁTUJĄCE WARUNKI ŻYCIA W PIOTRKOWIE TRYBUNALSKIM}

Na warunki życia w Piotrkowie Trybunalskim po transformacji ustrojowej silnie oddziałują czynniki wewnętrzne, związane z przemianami struktury demograficznej jego mieszkańców. Kluczowe znaczenie ma wśród nich depopulacja. W latach 1990-2012 o około
5\% spadła liczba mieszkańców, co wynika z malejącego od 1998 r. przyrostu naturalnego, wiążącego się ze spadkiem współczynnika płodności w grupie wiekowej kobiet 20-29 lat (którego nie zrównoważył wzrost w grupie wiekowej 30-39 lat) oraz ujemnego salda migracji wewnętrznych. Ponadto w okresie 1988-2011 r. ludność Piotrkowa wyraźnie postarzała się: o 11 punktów procentowych (p.p.) zmniejszył się odsetek dzieci i młodzieży, przybyło zaś osób w wieku produkcyjnym (o 5 p.p.) oraz poprodukcyjnym (o 6 p.p.).

Przebieg tych zmian w poszczególnych dzielnicach miasta był różny, na co miały wpływ panujące tam warunki życia. Dzielnicami zamieszkiwanymi w większym odsetku przez osoby starsze były w Piotrkowie rejony najbliższe historycznemu centrum, w których dominuje zabudowa wielorodzinna. Osób w wieku produkcyjnym więcej było po zachodniej stronie torów kolejowych, w dzielnicach o lepiej rozwiniętej infrastrukturze. Natomiast najmłodsi mieszkańcy są (względnie) najliczniejsi w dzielnicy staromiejskiej, w Centrum oraz dzielnicach nieco szybciej rozwijających się w ciągu ostatnich pięciu lat, a położonych we wschodniej stronie miasta, słabiej rozwiniętej infrastrukturalnie.

Wśród innych czynników endogenicznych oddziałujących na zmiany w przestrzeni miasta po transformacji ustrojowej należy wskazać niedorozwój infrastruktury technicznej (wodno-kanalizacyjnej), uniemożliwiający od początku lat 80. minionego wieku równomierny rozwój miasta na wschód i zachód, co tłumaczy zróżnicowanie $\mathrm{w}$ obu tych rejonach Piotrkowa. We wschodniej części około $2 / 3$ zabudowy powstało przed rokiem 1970. Są to głównie budynki wielorodzinne. Lepsza sytuacja jest po zachodniej stronie torów kolejowych, gdzie większość budynków powstała w latach 80. i 90. XX w. - jako domy jednorodzinne. Wyraźne zaniedbania uwidoczniły się w renowacji części staromiejskiej. Niewielką poprawę zaobserwowano tam dopiero po pojawieniu się zewnętrznych źródeł finansowania (środków unijnych). W roku 2007 rozpoczęto jej rewitalizację w ramach projektu „Trakt Wielu Kultur”, współfinansowanego ze środków Europejskiego Funduszu Rozwoju Regionalnego. W ramach tego projektu udało się odnowić elewacje Miejskiej Biblioteki Publicznej i zabytkowej Wieży Ciśnień oraz przebudować plac Czarnieckiego i jeszcze kilka ulic w staromiejskiej części Piotrkowa. Nadało to miastu nowego blasku, a jednocześnie wyostrzyło kontrasty panujące w przestrzeni historycznego centrum. 


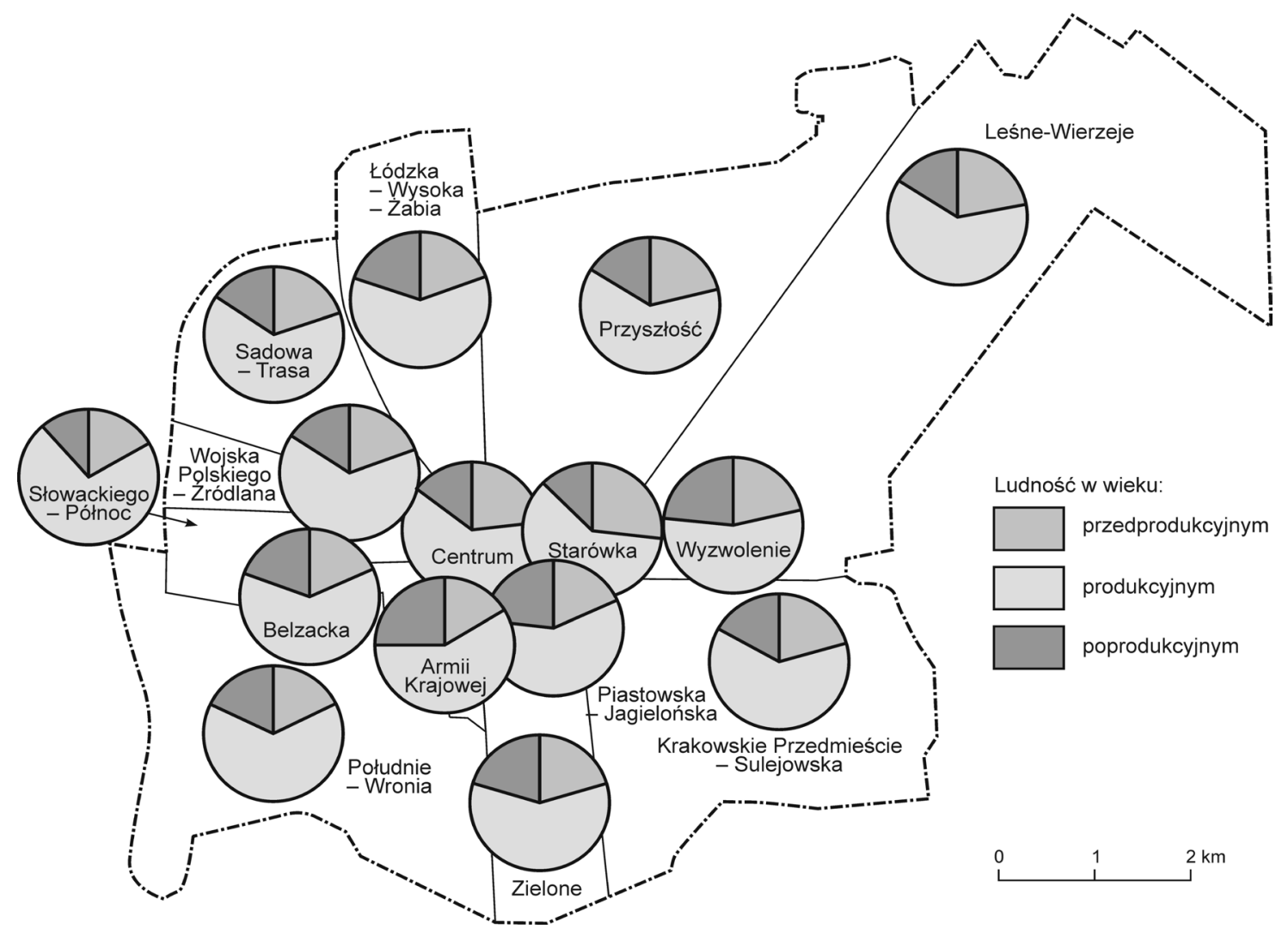

Rys. 2. Struktura wieku ludności Piotrkowa Trybunalskiego według dzielnic Źródło: opracowanie własne; wykorzystano program RegioGraph Planning 12

Wobec złego stanu infrastruktury konieczny był kompromis w ustalaniu potrzeb inwestycyjnych. Władze lokalne skoncentrowały się na rozwoju infrastruktury technicznej i drogowej (budowa obwodnicy miasta i oczyszczalni ścieków, remonty dworca PKP oraz wybranych ulic), zaniedbując inwestycyjnie obszar usług społecznych związanych ze zdrowiem, rekreacją czy kulturą. Największym problemem Piotrkowa jest niewystarczająca dostępność bibliotek - jedna placówka z dwiema filiami. Zły stan techniczny budynku tej biblioteki utrudnia uzupełnianie jej księgozbioru, co negatywnie wpływa na jakość świadczonych usług.

Zróżnicowania demograficzne oraz dysproporcje $\mathrm{w}$ rozwoju przestrzennym w Piotrkowie mają odzwierciedlenie $\mathrm{w}$ oczekiwaniach odnośnie do warunków życia w tym mieście. Zahamowanie (czy odwrócenie) niekorzystnych procesów demograficznych jest dużym wyzwaniem, w obliczu którego władze lokalne bez dodatkowego wsparcia pozostają bezsilne. Chcąc zaplanować skuteczne przeciwdziałanie negatywnym skutkom przemian konieczne jest jednak zdiagnozowanie ich przyczyn.
Posługując się regresją logistyczną obliczono prawdopodobieństwo chęci pozostania w swojej dzielnicy zamieszkania. Siła klasyfikacyjna, czyli prawdopodobieństwo odtworzenia za pomocą modelu decyzji respondentów, o pozostaniu w obecnej dzielnicy zamieszkania wyniosła $69 \%$. Wyniki analizy potwierdziły, że wyższe wykształcenie sprzyja decyzji o wyprowadzce z dzielnicy, a dłuższy okres zamieszkania działa w przeciwnym kierunku. Co ciekawe, na chęć pozostania na miejscu wpływa regularne korzystanie z dzielnicowej przychodni rodzinnej. Natomiast regularne korzystanie z biblioteki poza miejscem zamieszkania obniża chęć pozostania w dzielnicy. Wśród czytelników są z pewnością osoby korzystające z biblioteki nie tylko poza dzielnicą zamieszkania, ale wręcz $\mathrm{w}$ innym mieście, co stwarza możliwość porównania zróżnicowanych warunków życia. Tylko w dwóch dzielnicach $\mathrm{w}$ Piotrkowie mieszkańcy mają możliwość korzystania z biblioteki, a w czterech są trudności z dostępem do przychodni zdrowia. Mieszkańcy korzystają z tych placówek poza dzielnicą, w rejonach oddalonych od centrum miasta. Są to zarazem dzielnice o korzystnej (dość młodej) strukturze wieku lud- 
ności, co oznacza, że wraz z upływem czasu popyt na usługi zdrowotne będzie rósł.

$\mathrm{Na}$ dalszym etapie badań analizowano najbardziej istotne dla mieszkańców cechy własnego środowiska zamieszkania w konfrontacji z ich oczekiwaniami. $\mathrm{Na}$ tej podstawie możliwe było zdiagnozowanie najbardziej pożądanego przez mieszkańców kierunku przemian. Opracowano zestaw czynników opisujących wady i zalety środowiska mieszkalnego, które podzielono na cztery kategorie (ekologiczne, estetyczno-urbanistyczne, prestiżowe, egzystencjalne) i zestawiono w pary przeciwstawnych cech (tab. 1).

Zastosowano analizę łącznego oddziaływania zmiennych (ang. conjoint) mierzącej preferencje w kontekście różnych cech badanego obiektu. Wykorzystano podejście CBC (ang. choice based conjoint) oraz metodę obliczeniową, opierającą się na bayesowskiej estymacji hierarchicznej, która ujawnia nawet niewielkie różnice w preferencjach (często wprost nie są one uświadamiane).

Tab. 1. Składniki oceny przestrzeni społecznej w Piotrkowie

\begin{tabular}{|l|l|}
\hline $\begin{array}{c}\text { Rodzaj składnika } \\
\text { oceny }\end{array}$ & Zestawy cech wymienianych w ocenie \\
\hline \multirow{2}{*}{ Ekologiczny } & - cisza - hałas \\
& - czystość - brud \\
& - dużo zieleni - mało zieleni \\
& czyste powietrze - zanieczyszczone \\
& powietrze
\end{tabular}

Źródło: opracowanie własne.

W przypadku opisu dzielnicy idealnej nie odnotowano większego zróżnicowania w zależności od miejsca zamieszkania. Szczególnie dotyczyło to trzech najpopularniejszych cech. Mieszkańcy wszystkich dzielnic byli zgodni co do tego, że idealna dzielnica to taka, w której mieszkają „mili” ludzie (52\%). Niewielkie zróżnicowanie przestrzenne wyników zaobserwowano na pozycji drugiej i trzeciej, przy czym zazwyczaj mieszkańcy wskazywali jako drugą pod względem ważności „ładną zabudowę” (11\%), zamiennie z „bezpieczeństwem” (9\%).

Większe zróżnicowania przestrzenne uwidocznione zostały przy pozycjonowaniu (od najważniejszych do mniej ważnych) cech opisujących dzielnicę, w której mieszkali respondenci. W skali całego miasta w rankingu pierwszych trzech atrybutów znalazły się w kolejności: „wyposażenie w instalacje” (11\%), „bezpieczeństwo” (8\%), „zła organizacja przestrzeni” (8\%). W poszczególnych dzielnicach na pierwszym miejscu były wymieniane przeważnie zalety środowisk zamieszkania, choć mieszkańcy pięciu opisali swoją dzielnicę zaczynając od wad. W ośmiu dzielnicach na kolejnych trzech miejscach znalazły się wyłącznie zalety, a tylko w przypadku dzielnicy Słowackiego-Północ wymieniono dwie wady tej dzielnicy. Ma to związek nie tylko z obserwowanym stanem, lecz i ze świadomością funkcji, które dzielnica pełni w przestrzeni miasta - jest ona bowiem handlowym centrum. Uwage zwraca ponadto historyczne centrum miasta. Choć jego mieszkańcy nie zaczynali opisu swojej dzielnicy od negatywnych atrybutów, to jednak różnice pomiędzy poszczególnymi cechami dzielnicy były niewielkie. Na kolejnych dwóch miejscach pojawiły się: „brzydka zabudowa” i „brud”. Jest to jedna z surowszych opinii na tle innych obszarów Piotrkowa (w odniesieniu do wszystkich atrybutów). Odnowienie fasad kamienic w Rynku i nawierzchni ulic poprawiło nieco zły stan Starego Miasta, ale wyostrzyło istniejące kontrasty i uwidoczniło nowe potrzeby inwestycyjne.

W części staromiejskiej Piotrkowa znajdują się miejsca symboliczne, które mogą stanowić przedmiot dumy w kontaktach ze społecznością ponadlokalną i wpływać na identyfikację z miejscem zamieszkania. Respondenci uznali, że są to: Zamek (68\%), Rynek Trybunalski (64\%) oraz kościół Bernardynów (61\%). Co interesujące, były to atrakcje najczęściej polecane rodzinie czy przyjezdnym z zagranicy. Wśród wymienianych obiektów tego typu w pierwszej dziesiątce pojawiły się w obu kategoriach także: Wieża Ciśnień, fara, kościół Jezuitów, cerkiew, Krzywda ${ }^{1}$, galeria handlowa Focus Mall i ulica Słowackiego.

W wyniku analizy zdiagnozowano kluczowy pod względem urbanistycznoestetycznym obszar proble- 
mowy. Ten pesymistyczny obraz ładu przestrzennego wdzielnicach Piotrkowa jest wyraźnym sygnałem wskazującym pilny kierunek oczekiwanych przemian: poprawy stanu zabudowy, zagospodarowania i estetyki przestrzeni w mieście.

\section{ODDZIAŁYWANIE CZYNNIKÓW EGZOGENICZNYCH NA ROZWÓJ PIOTRKOWA}

Procesy transformacyjne w skali makro spowodowały przeobrażenia w gospodarce miasta. Kluczowy był tu proces deindustrializacji, powodujący wzrost liczby bezrobotnych. Szczególnie na przełomie XX i XXI w. dynamicznie wzrastała ta liczba (w 2006 r. zbliżyła się do 10 tys.), a większość $\mathrm{z}$ nich poszukiwała wówczas pracy ponad 12 miesięcy. O niedopasowaniu podaży na lokalnym rynku pracy do potrzeb świadczy struktura osób bezrobotnych według wykształcenia. Wraz z upływem czasu wzrastała liczba bezrobotnych z wykształceniem wyższym (o ok. 20 p.p.), zmalał zaś odsetek osób bezrobotnych z przygotowaniem średnim zawodowym (o ok. 10 p.p.). Dalsze niedopasowania ujawnia struktura bezrobotnych według wieku. Odnotowano bowiem spadek odsetka osób bezrobotnych w wieku 18-24 lata, przy wzroście w grupie wiekowej 25-34 lata i osób najstarszych (powyżej 55 lat).

Większe zainteresowanie inwestorów zagranicznych realizacją przedsięwzięć w Piotrkowie obserwowano po wprowadzeniu lokalnych zwolnień podatkowych dla firm inwestujących w mieście oraz utworzeniu tu podstrefy Łódzkiej Specjalnej Strefy Ekonomicznej. Mimo że powstały dwa największe przedsiębiorstwa działające w sektorze prywatnym (Häring, Emmerson), nie wpłynęło to w sposób przełomowy na dochody miasta ani na warunki życia. Przygotowane do inwestycji tereny oczekują na kolejne lokaty kapitału, jednak potrzebne są tu dalsze działania promujące.

Wyniki badania wykazały trafność oceny bieżącej sytuacji w mieście, co przejawiało się spójnością w opisie hamulców i motorów wzrostu. Piotrkowianie wskazali więcej czynników wspierających rozwój miasta niż ograniczeń. Może to świadczyć o dość dużym rozczarowaniu obserwowaną sytuacją, wiążącą się z widocznym brakiem efektywności władz $\mathrm{w}$ tej dziedzinie. Za główny czynnik, który $\mathrm{w}$ największym stopniu wpływał hamująco na przeobrażenia w mieście uznali oni osłabienie bazy ekonomicznej: zamykanie dużych zakładów pracy i brak inwestycji tworzących nowe miejsca pracy (odpowiednio 69\% i 63\% wskazań) (rys. 3). Pierwsza kwestia była szczególnie istotna dla osób w średnim wieku (które $\mathrm{z}$ niepokojem myślą o swojej przyszłości) oraz dla rdzennych mieszkańców Piotrkowa (zamieszkałych tu od co najmniej 21 lat) z mieszkaniami w okolicy zamkniętych zakładów przemysłowych, obserwujących konsekwencje tego upadku.

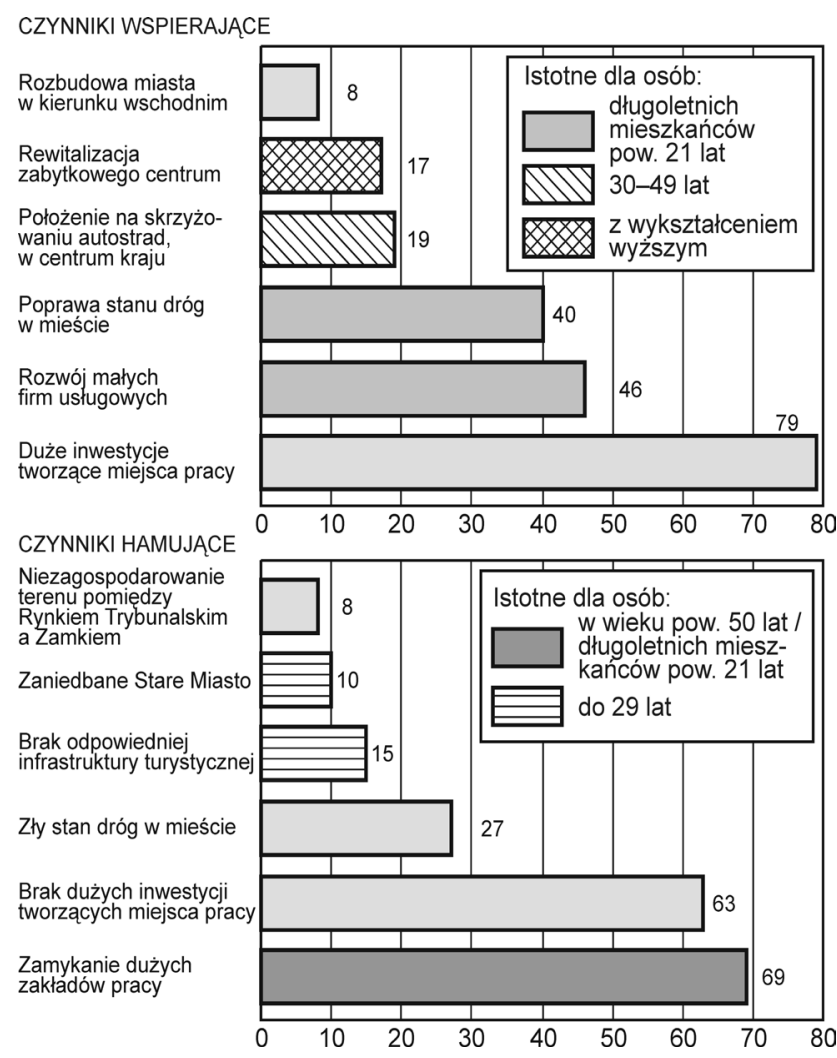

Rys. 3. Czynniki wspierające (A) i hamujące (B) rozwój Piotrkowa w opinii jego mieszkańców

Uwaga - odsetki nie sumują się do 100\%

Źródło: opracowanie autorki na podstawie badań własnych

Na brak dużych inwestycji narzekali ponadto mieszkańcy dzielnic położonych na obrzeżach miasta przygotowanych do lokalizacji nowych przedsiębiorstw. Na ten zastój przemysłowy wpływał (zdaniem piotrkowian) zły stan dróg miejskich, co podkreślano szczególnie w dzielnicach zachodnich, przejmujących w pierwszej kolejności ruch tranzytowy $\mathrm{z}$ autostrady A1 z Łodzi oraz drogi szybkiego ruchu z Częstochowy i Warszawy. Na wartości historyczne wskazywano nieco rzadziej, łącząc je z zaniedbaniami w wyposażeniu w infrastrukturę turystyczną. Obie te kwestie poruszali zwykle młodzi piotrkowianie, w wieku do 29 lat.

Sposobem na poprawę społeczno-gospodarczej sytuacji Piotrkowa według 79\% ankietowanych miesz- 
kańców miasta mogą być duże inwestycje tworzące miejsca pracy. Takie stanowisko prezentowały zwłaszcza osoby mieszkające w Piotrkowie od co najmniej 21 lat i dobrze pamiętające rozwój miasta dzięki industrializacji, a także mieszkańcy południowych dzielnic miasta, które wciąż pełnią częściowo funkcję rolniczą lub mieszkaniowo-administracyjną. Takiego zdania byli też mieszkańcy dawnej dzielnicy przemysłowej. Drugim wymienianym przez piotrkowian sposobem na sukces gospodarczy byłoby wspieranie małych firm usługowych, na co wskazywali zwłaszcza mieszkańcy dzielnic dysponujących potencjałem dla rozwoju tego sektora gospodarki Piotrkowa. Sprzyjająco na rozwój miasta wpłynęłaby też poprawa stanu dróg, istotna dla mieszkańców dzielnic Przyszłość na północy oraz Słowackiego-Północ i Południe-Wronia na południowym zachodzie. Pierwsza z nich dysponuje dużym zasobem gruntów, lecz dla przyciągnięcia inwestycji zewnętrznych brak jej infrastruktury drogowej i technicznej. $\mathrm{Z}$ kolei dwie pozostałe dzielnice potrzebują ciągłych modernizacji tamtejszej sieci drogowej i jej rozbudowy.

\section{PERSPEKTYWY ROZWOJU PIOTRKOWA TRYBUNALSKIEGO}

W roku 2017 miasto obchodzi 800-lecie pierwszej o nim wzmianki². Sprzyja to podsumowaniom oraz planowaniu kolejnych projektów rozwojowych. Wraz z depopulacją, przejawiającą się spadkiem liczby ludności miasta oraz wzrostem wśród niej odsetka osób w wieku poprodukcyjnym, budżet Piotrkowa podlega podwójnej presji: spadają wpływy podatkowe, a rosną wydatki na opiekę i pomoc społeczną. Dlatego władze miasta powinny podejmować działania w celu odbudowy zasobów endogenicznych, które mogłyby obejmować:

1. Rewitalizację dzielnicy staromiejskiej oraz stworzenie oferty turystyczno-gastronomicznej w okolicy Zamku, pobudzającej ruch turystyczno-rekreacyjny.

2. Odnowę fizycznej tkanki miasta, szczególnie centralnego odcinka ulicy Słowackiego, oraz wyremontowanie zabytkowych kamienic wokolicy Domu Kultury.

3. Zwiększenie dostępności bibliotek, poprzez realizację odkładanego projektu budowy nowoczesnej biblioteki na placu pofranciszkańskim, oraz otwarcia filii w nowych osiedlach.

4. Podniesienie atrakcyjności inwestycyjnej wschodniej części miasta poprzez zagospodarowanie budynku po przędzalni (dawnego Sigmatexu), uporządkowanie sytuacji prawnej jeziora Bugaj, uzbrojenie i udostępnienie terenu inwestorom.

5. Stworzenie konkurencyjnej oferty terenów pod budownictwo mieszkaniowe wraz $\mathrm{z}$ infrastrukturą społeczną (placówki opieki zdrowotnej) oraz techniczną i drogową.

Planowane na szczeblu lokalnym działania mogą być niewystarczające bez wsparcia programów krajowych, gdyż dobra lokalizacja miasta przy głównych szlakach komunikacyjnych w obecnej sytuacji Polski nie ma kluczowego znaczenia (inne ośrodki, potencjalnie konkurencyjne, zyskały na intensywnym rozwoju infrastruktury komunikacyjnej po wstąpieniu Polski do UE).

\section{PRZYPISY}

1 Krzywda to potoczna nazwa parku śródmiejskiego im. Jana Pawła II, przy ul. Słowackiego - położonego w najbardziej reprezentacyjnej części miasta. Miejsce po pięciu kamienicach zniszczonych podczas nalotów niemieckich we wrześniu 1939 r.

${ }^{2}$ Petrecoue - zob. J. Kwiatek, T. Lijewski (1998, s. 637).

\section{BIBLIOGRAFIA}

Czapiński J., Panek T. (red.), 2014, Diagnoza społeczna Polaków 2013: warunki i jakość życia Polaków, MPiPS, Warszawa.

Drewnowski J., 1974, On measuring and planning the quality of life, Mouton, The Hague-Paris.

Gillingham R., Reece W.S., 1980, Analytical problems in measurement of the quality of life, „Social Indicators Research”, 1-4.

Hodoly A., 1975, Spożycie i formy jego realizacji w rozwoju gospodarki społeczenístwa socjalistycznego, Biblioteka IHW, Warszawa.

Kwiatek J., Lijewski T., 1998, Leksykon miast polskich, Warszawa. Liszewski S., 1995, Zróżnicowanie przestrzenne poziomu i jakości warunków życia ludności w aglomeracjach miejskich, „Acta Universitatis Lodziensis. Folia Geographica", 20, s. 207-219.

Liszewski S., 2004, Rola i zadania geografii $w$ badaniach zróżnicowania przestrzennego warunków życia mieszkańców miast. Założenia teoretyczne i program badań, [w:] I. Jażdżewska (red.), Zróżnicowanie warunków życia ludności w mieście, XVII „Konwersatorium Wiedzy o Mieście”, Uniwersytet Łódzki, Łodź, s. 7-18.

Matykowski R., 1992, Zbieranie i tworzenie informacji $w$ badaniach społeczno-geograficznych: problemy i trudności, [w:] Z. Chojnicki, T. Czyż (red.), Współczesne problemy geografii społeczno-ekonomicznej Polski, Ser. „Geografia”, 55, Uniwersytet im. Adama Mickiewicza, Poznań, s. 149-161. 
Misiak W., 1992, Jakość życia w zróżnicowanych strefach Wrocławia, [w:] Środowisko ekologiczne Wrocławia. Materiały sesji naukowej, Wrocławskie Towarzystwo Naukowe, Wrocław.

Parysek J.J., 2005, Miasta polskie na przełomie XX i XXI wieku. Rozwój i przekształcenia strukturalne, Bogucki Wyd. Naukowe, Poznań.

Pohorille M., 1977, Dobrobyt społeczny: pojęcie, mierzenie, metoda analizy, „Ekonomista”, 5.

Regulski J., 1982, Ekonomika miasta, Państwowe Wyd. Ekonomiczne, Warszawa.

Rogerson R., 1999, Quality of life and city competitiveness, „Urban Studies”, 36, 5-6, s. 969-985 (GUS, 2011).
Słaby T., 1990, Poziom życia, jakość życia, „Wiadomości Statystyczne", 6.

Stiglitz J.E., Sen A., Fitoussi J.P., 2009, Report by the Commission on the Measurement of Economic Performance and Social Progress, www.insee.fr/fr/publications-et-services/default. asp?page=dossiers_web/stiglitz/documents-commission.htm; 11.05.2016

Zborowski A., 1989, Spatial differentiation of living standards as effect of social urbanization processes in Upper Silesia - Cracow Agglomeration, „Bochumer Geographische Arbeiten", 51.

Artykuł wpłynął

24 maja 2017 